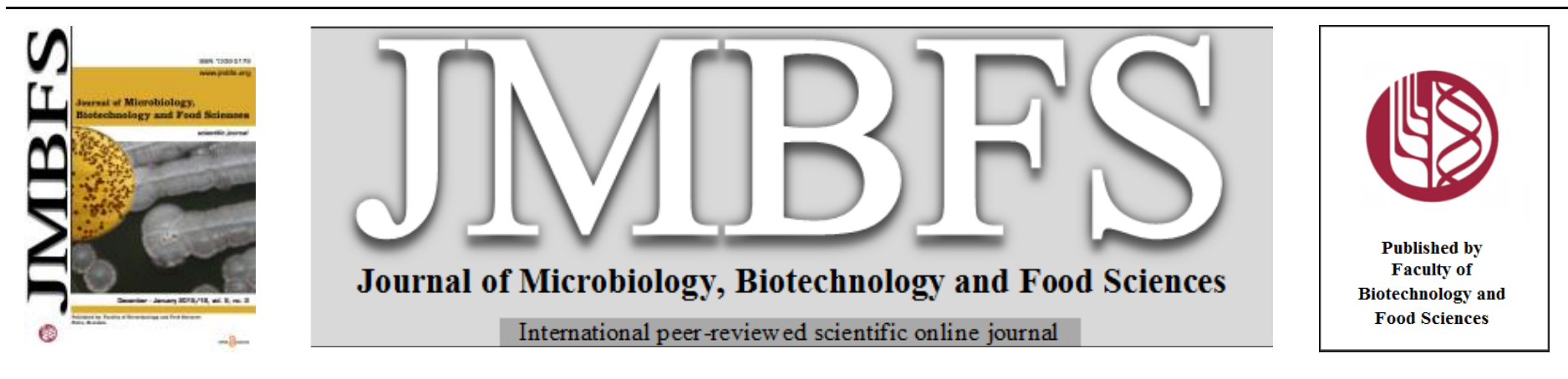

\title{
PRODUCTION OF CONCOCTION WINE USING PALM SAP AND RAISIN THROUGH BATCH FERMENTATION
}

\author{
Vinayaka B. Shet, Prasanna D. Belur*
}

Address(es): Dr. Prasanna D. Belur,

Dept. of Chemical Engg, National Institute of Technology Karnataka, Surathkal- 575 025, Managlore, India, Phone: +919483035265.

*Corresponding author: prsnbhat@gmail.com

doi: 10.15414/jmbfs.2015/16.5.3.293-296

ARTICLE INFO

Received 19.8.2015

Revised 2. 10. 2015

Accepted 18. 11. 2015

Published 1. 12. 2015

Regular article

OPEN $\partial_{\text {ACCESS }}$

\begin{abstract}
Palm wine is a common cheap beverage, widely consumed in parts Africa, Asia and South America. The sap obtained from Palm tree is fermented to produce Palm wine. In the current study palm sap was blended with raisins. After processing, extract was subjected to anaerobic fermentation by inoculating Saccharomyces cerevisiae with an initial $\mathrm{pH}$ of 3.5 and initial sugar content of $22-24^{\circ}$ Brix at room temperature. Wine was then subjected to malolactic fermentation using Oenococcus oeni. The ethanol concentration was found to be in the range of $12-13 \%(\mathrm{v} / \mathrm{v})$, and residual sugar concentration was found to be less than $2 \mathrm{mg} / \mathrm{ml}$. Fixed acidity in terms of tartaric acid equivalent was found to be in the range of $3.31 \mathrm{~g} / \mathrm{L}$ to $6.18 \mathrm{~g} / \mathrm{L}$, radical scavenging activity in terms of trolox equivalent was found to be in the range 2.3-2.5mmol TE /L. Various metals such as $\mathrm{Cr}, \mathrm{Cd}, \mathrm{Cu}, \mathrm{Mn}, \mathrm{Ni}, \mathrm{Pb}$ and $\mathrm{Zn}$ were estimated. In total this concoction wine was comparable with typical grape wine. This work proves that there is a potential to convert cheap palm sap into value added concoction wine.
\end{abstract}

Keywords: Concoction wine, Oenococcus oeni, Palm sap, Raisins

\section{INTRODUCTION}

Text Palm wine also called as palm toddy or simply toddy is an alcoholic beverage obtained by the fermentation of the sap from the palm tree (Okafor, 1972; Lasekan et al., 2009). Palm wine is a common cheap beverage, widely consumed in parts Africa, Asia and South America. Wild date (Phoenix sylvestris), Coconut (Cocos nucifera L), Palmyra palm (Borassus flabellifer), sago palm (Metroxylan sago) and toddy palms (Phoenix humilis var. pedunculata) are frequently used for this purpose. Palm wine is obtained by the natural fermentation of palm sap and collected through the tapping of unopened inflorescence. Sap obtained from coconut palm is often called as "Neera" in India (Law et al., 2011). Palm wine has mild alcoholic flavour, sweet in taste, vigorous effervescence and milky white in colour as it contained suspension of numerous bacteria and yeast. It thus serves as a rich dietary source of vitamins of the "B" complex (Tuley, 1965; Lasekan et al., 2009).

Fresh coconut sap contained $12-15 \%$ of sucrose (by weight) and trace amount of reducing sugar including glucose, fructose, maltose and raffinose (Michael, 1988). The sap contains approximately $0.23 \%$ protein, $0.02 \%$ fat. Half of the total sugars are fermented during first 24 hours and ethanol content of the fermented palm sap reaches maximum of $5.0-5.28 \%(\mathrm{v} / \mathrm{v})$ after 48 hours (Sekar and Mariappan, 2005). Natural fermentation of fresh sap also results in the formation of various undesirable products such as acetic acid which in turn affects the taste (Shamala, 1988). Due to weak alcoholic strength, milky white turbid appearance and presence of off-odour palm wine is still considered as a cheap beverage and hence generate very low revenue for the palm farmers. Absence of translucent colour and characteristic taste (palate), which is the desirable characteristic feature of grape wines is absent in palm wine resulted in least preference for palm wine among wine drinkers.

The sap is collected from slits along the unexpanded flower spathes and is immediately inoculated by various wild yeasts and bacteria naturally, triggers the fermentation process. Several researchers tried to arrest fermentation by adding various antimicrobial agents (Morah, 1994) and reported a better quality beverage by carrying out controlled fermentation using selected yeast strains. However to achieve good alcoholic strength in the wine, it becomes imperative to increase the Brix of palm sap from $12-15$ to 24 . Generally table sugar is employed for increasing the initial sugar concentration.

In the current study, controlled fermentation of fresh sap of Cocos nucifera $\mathrm{L}$ and Borassus flabellifer was carried out using Saccharomyces cerevisiae. The fresh sap was supplemented with calculated quantity of cabernet sauvignon raisins so as to get a final Brix of 24 and fermented with the expectation that the raisins compliment the sap by imparting colour and palate.

\section{MATERIAL AND METHODS}

\section{Collection of palm sap}

Fresh sap was collected from Cocos nucifera $\mathrm{L}$ tree and Borassus flabellifer tree by professional tappers was used for the study. To avoid the fermentation by contaminating wild yeasts and bacteria, about $200 \mathrm{mg} \mathrm{kg}^{-1}$ of potassium metabisulphite was added to earthen mud pot prior to collection of palm sap (Morah, 1994). Palm sap was collected early morning and subsequent evening, transported immediately to the lab, stored in freezer at $-20^{\circ} \mathrm{C}$ till further use.

\section{Mash preparation}

Based upon the sugar content of the sap and sugar content of Cabernet Sauvignon raisin, calculated quantity of raisins were taken and soaked in palm sap and heated to $90^{\circ} \mathrm{C}$ for 15 minutes to reduce the microbial load thereby arrest the commencement of fermentation by contaminant organisms. Once steeping is over, the raisins are crushed using domestic blender. The sugar concentration of the mash was measured using refractometer and adjusted to $22^{\circ}-24^{\circ}$ Brix. Tartaric acid crystals are used to adjust the $\mathrm{pH}$ to 3.5 .

To determine the best possible combination of palm sap and raisins, several combinations of both were taken as given in Table 1 .

\section{Fermentation}

Dry yeast (Saccharomyces cerevisiae) was rehydrated by adding $10 \mathrm{ml}$ of water to $1 \mathrm{~g}$ of dry yeast, and allowed to stand for $15 \mathrm{~min}$ and then few drops of raisin extract was added and incubated for another $15 \mathrm{~min}$. Once effervescence was visible, mash was pitched at the rate of $1 \mathrm{~g}$ dry yeast per litre. Fermentation was carried out at $16^{\circ} \mathrm{C} \pm 2{ }^{\circ} \mathrm{C}$ in conical flasks fitted with centrally bored cork having airlock. Fermentation was carried out till no more effervescence was noticed.

Once the yeast fermentation came to an end, malolactic fermentation was initiated by inoculating Oenococcus oeni bacteria, and allowed to ferment for another 21 days. After the alcoholic and malolactic fermentation, centrifugation of wine was carried out to remove the biomass and particulate matter Centrifugation was carried out at $8000 \mathrm{rpm}$ for $15 \mathrm{~min}$. and clarified wine was taken for analysis. 
Table 1 Combination of raisin and palm sap taken for fermentation studies.

\begin{tabular}{lccc}
\hline Name & $\begin{array}{c}\text { Cabernet Sauvignon } \\
\text { raisin }(\mathrm{g})\end{array}$ & $\begin{array}{c}\text { Cocos nucifera } \mathbf{L} \\
\text { sap }(\mathbf{m l})\end{array}$ & $\begin{array}{c}\text { Borassus } \\
\text { flabellifer Sap } \\
(\mathbf{m l})\end{array}$ \\
\hline $\mathrm{N}_{2}$ & 350 & -- & 500 \\
$\mathrm{~N}_{3}$ & 200 & 500 & -- \\
$\mathrm{N}_{4}$ & 100 & 500 & -- \\
$\mathrm{N}_{5}$ & 350 & 500 & -- \\
\hline
\end{tabular}

\section{Analysis}

\section{Soluble solid (Sugar)}

The residual sugar concentration was estimated using Refractometer (ATAGO, RX-5000 $\alpha$-Plus). The use of refractometric techniques has become widespread in a number of fields due to its accuracy, reduced size, response velocity and immunity to electromagnetic interference (Marquez et al., 2013).

\section{Titratable Acids Assay}

Titratable acidity (TA) was determined by titration of a strong base agains sample to an end point of $\mathrm{pH} 8.2$ using potentiometric titration (Jacobson, 2006).

\section{Volatile acid assay}

Wine samples were distilled and the distillate was titrated against $\mathrm{NaOH}$ using phenolphthalein as indicator to determine volatile acid content (Moura $\boldsymbol{e t}$ al. 2010).

\section{Polyphenols analysis by HPLC}

Analysis of polyphenols was performed using HPLC (Dionex 3000) , using C-18 Phenomenex column with length $150 \mathrm{~mm}$ and internal diameter $4.6 \mathrm{~mm}$. The mobile phase was acetonitrile-water- acetic acid at a volume ratio of 20: 82: 1 $(\mathrm{v} / \mathrm{v} / \mathrm{v})$. Flow rate, column temperature and detection wavelength were set at 1.0 $\mathrm{ml} / \mathrm{min}, 30^{\circ} \mathrm{C}$ and $280 \mathrm{~nm}$ (Seruga et al., 2011) respectively and the separation time was less than 30 minutes. Extract of $20 \mu \mathrm{L}$ volume was used as sample for injection. Pure chemicals purchased from sigma-Aldrich (India) were used for calibrating HPLC for gallic acid, caffeic acid, syringic acid and p-coumaric acid (Budak et al., 2010).

\section{Metal analysis by AAS}

Metal analysis was carried out by Atomic absorption Spectroscopy (GBC Avanta) after carrying out acid digestion of the wine samples. $2 \mathrm{ml}$ of wine sample was taken in $250 \mathrm{ml}$ digestion flask, mixed with freshly prepared $10 \mathrm{ml}$ $\mathrm{HNO}_{3} / \mathrm{H}_{2} \mathrm{O}_{2}$ mixture and $10 \mathrm{ml}$ Hydrochloric acid, incubated at $60^{\circ} \mathrm{C}$. Heating was continued until the solution becomes clear and colourless (Woldemariam et al., 2011). The cooled digest was made up to $100 \mathrm{ml}$, by adding deionised ultra-pure water, stored in refrigerator for further analysis (Nikolakaki et al., 2002) Standard metal solution of three different concentrations was prepared for calibration.

\section{Antioxidant assay}

Antioxidant activity of wine samples were analysed by the 2, 2 diphenylpicrylhydrazyl (DPPH) method (Seruga et al., 2011). $50 \mu \mathrm{L}$ of wine sample was mixed with $120 \mu \mathrm{L}$ of methanolic DPPH solution $\left(1 \mathrm{mmol} \mathrm{dm}^{-3}\right)$ and $1880 \mu \mathrm{L}$ of methanol to attain a final concentration of DPPH in the reaction mixture of $5.85 \times 10^{-5} \mathrm{~mol} \mathrm{dm}^{-3}$. The reaction mixture was kept in the dark at room temperature for $15 \mathrm{~min}$ and then the absorbance at $517 \mathrm{~nm}$ of this mixture (A wine) was measured against the blank sample $(50 \mu \mathrm{L}$ of diluted wine, $2000 \mu \mathrm{L}$ of methanol). The DPPH blank solution was prepared fresh $(120 \mu \mathrm{L}$ of $1 \mathrm{mmol}$ dm -3 DPPH, 1930 micro L of methanol) and its absorbance at $517 \mathrm{~nm}$ (A $\mathrm{DPPH})$ was measured. Trolox standards with final concentration $0-2550 \mu \mathrm{mol} / \mathrm{L}$ in methanol were assayed under the same conditions as those used for the wine samples; i.e. $50 \mu \mathrm{L}$ of Trolox was mixed with $120 \mu \mathrm{L}$ of methanolic $1 \mathrm{mmol} / \mathrm{L}$ DPPH solution and $1880 \mu \mathrm{L}$ of methanol. After $15 \mathrm{~min}$, the absorbance at 517 nm (A Trolox) against the prepared blank sample was measured. The calibration curve for Trolox, constructed by linear regression of absorbance value (A Trolox) vs. Trolox concentration, was used to calculate the antioxidant activity of wine sample and to express their anti oxidant value in mmol of Trolox equivalents (mmol TE/L) (Seruga et al., 2011)

\section{Residual sugar estimation}

The concentration of residual sugars was estimated by the colorimetric method using the UV Vis spectrophotometer at $540 \mathrm{~nm}$ with 3, 5- DNSA reagent (Miller, 1959).

\section{Quantitative estimation of ethanol}

Ethanol concentrations in wine samples were estimated using gas chromatography (Shimadzu GC-2014). Injection port; column and FID detector temperature was set $235^{\circ} \mathrm{C}, 55^{\circ} \mathrm{C}$ and $250^{\circ} \mathrm{C}$ respectively. Column temperature was varied from $55^{\circ} \mathrm{C}$ to $80^{\circ} \mathrm{C}$ at a rate of $5^{\circ} \mathrm{C}$ per min and maintained for $3 \mathrm{~min}$. Flow rate of carrier gas was maintained to $8 \mathrm{ml} / \mathrm{min}$.

\section{RESULTS AND DISCUSSION}

\section{Estimation of soluble solids}

The estimation of the soluble solids was evaluated in order to check the progress of batch fermentation process. Grape soluble solids are expressed as Brix of sugar and it is estimated using refractometer (Bindon et al., 2013). In the current investigation initial soluble solids were maintained between $22^{\circ}-24^{\circ}$ Brix. It was observed that there was a steep decrease in Brix value during fermentation (Jacobson, 2006). After fermentation, a constant value of Brix was observed, which was possibly due to the presence of by products present during the palm sap collection, which further must have inhibited the growth of yeast. Secondly, the blend of palm sap and raisin contain sugars like raffinose, rhamnose, xylose and arabinose, which cannot be metabolised by yeast, contributes Brix value along with other dissolved molecules present in the broth. Initial soluble solids of fresh toddy of $5^{\circ}$ Brix reported (Shamala et al., 1988) and Cabernet Sauvignon grape was 20 to $26^{\circ}$ Brix (Bindon et al., 2013).

\section{Acidity}

\section{Volatile acidity (VA)}

VA is expressed as amount of acetic acid present in wine. The result reveals the presence of acetic acid in the wine. Oenococcus oeni produces acetic acid as by product (Olguin et al., 2009). In the current investigation volatile acidity estimated was 0.7 to $2.3 \mathrm{~g} / \mathrm{L}$ acetic acid. $\mathrm{N} 2$ combination was reported higher VA of $2.3 \mathrm{~g} / \mathrm{L}$ acetic acid. N4 combination reported low VA of $0.7 \mathrm{~g} / \mathrm{L}$ acetic acid. Low value of VA signifies that during the malolactic fermentation using Oenococcus oeni has reached the death phase soon compare to other combinations. N2 combination has higher value of VA and low value of residual sugar. The results clearly indicate that Oenococcus oeni has metabolized soluble solids to maximum extent during malolactic fermentation and produced more acetic acid as by product. Volatile acidity was reported (Moura et al., 2010) to be 1.12 to $2.80 \mathrm{~g} / \mathrm{L}$ acetic acid for red wine. VA of pomegranate wine was reported between 0.26 to $0.36 \mathrm{~g} / \mathrm{L}$ acetic acid (Mena et al., 2012)

\section{Titratable acidity (TA)}

$\mathrm{TA}(\mathrm{g} / \mathrm{L})=75 \times \mathrm{N} \times(\mathrm{T} / \mathrm{S})$

Where $\mathrm{N}$ is the normality of $\mathrm{NaOH}, \mathrm{T}$ is the titer volume (in $\mathrm{ml}$ ), $\mathrm{S}$ is the sample volume (in ml), and 75 is a constant. Moura et al., (2010) reported TA of 7.05 to $9.83 \mathrm{~g} / \mathrm{L}$ tartaric acid. Vahl et al., (2013) reported TA in the range of 4.80 to 6.24 $\mathrm{g} / \mathrm{L}$ tartaric acid. TA estimated in the current investigation is in the range of 4.01 to $9.99 \mathrm{~g} / \mathrm{L}$ tartaric acid.

\section{Fixed acidity (FA)}

Total acidity $=$ Fixed acidity + Volatile acidity

As per the Organisation of Vine and Wine (OIV) norms FA should not be less than 5g/L.Fig. 1 clearly indicates $\mathrm{N} 2$ and $\mathrm{N} 5$ contain FA as per the OIV. N3, N4 blending combination was found to have FA less than $5 \mathrm{~g} / \mathrm{L}$ as shown in Fig.1 


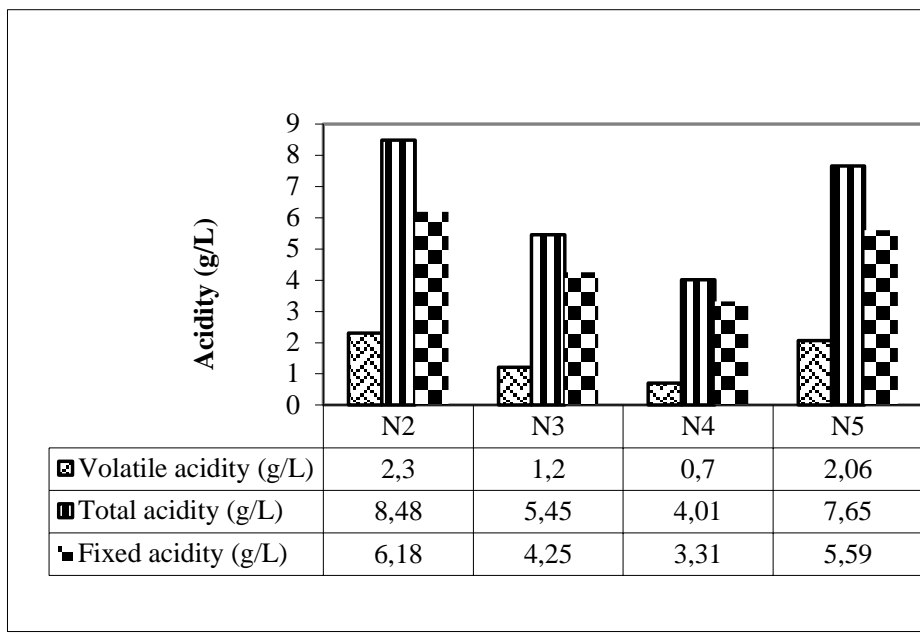

Figure 1 - Acidity of blended combination

\section{Polyphenols}

Syringic acid, caffeic acid, P-Glucinol, gallic acid were estimated in blended palm wine. In the present investigation concentration of polyphenols were estimated as follows: Gallic acid (5.42-105 mg/L), P-Glucinol (499.99-9678.22 $\mathrm{mg} / \mathrm{L})$, Caffeic acid $(0.07-2.94 \mathrm{mg} / \mathrm{L})$, Syringic acid $(0.32-1.19 \mathrm{mg} / \mathrm{L})$ Concentration of gallic acid was estimated maximum in N2. Similarly PGlucinol, Caffeic acid, Syringic acid in N1, N2, N3 respectively as shown in Table 2.

Presence of gallic acid in red wines from New Zeland and Australia were 37 to $108 \mathrm{mg} / \mathrm{L}$. Similarly in Italian red wines $47.21-325.48 \mathrm{mg} / \mathrm{L}$ and Hungarian red wines gallic acid content of 29.7-79.2 mg/L (Seruga et al., 2011). N2 has 105 $\mathrm{mg} / \mathrm{L}$ almost equivalent to the concentration of gallic acid reported Australian red wine. Caffeic acid concentration in white wine was reported 27.2 to $49.6 \mathrm{mg} / \mathrm{L}$ (Fracassetti et al., 2011). All the combination of current investigation is having lower concentration of Caffeic acid. It is probably due to the raisin must had lower concentration of gallic acid. Syringic acid was reported $6.0-23.9 \mathrm{mg} / \mathrm{L}$ in red wines (Garaguso et al., 2015). It is much higher than N2 to N5 combination investigated in current study. Phloroglucinol estimated in N2 was $9678.22 \mathrm{mg} / \mathrm{L}$. It is the highest among all the four combination. N4 was found lowest concentration of $499.99 \mathrm{mg} / \mathrm{L}$. N3 and N5 was estimated $9090.4 \mathrm{mg} / \mathrm{L}$ and $2569.83 \mathrm{mg} / \mathrm{L}$ respectively.

Table 2 Concentration of polyphenols (mg /L) estimated by HPLC method.

\begin{tabular}{lllll}
\hline Wine & Syringic acid & Caffeic acid & P-Glucinol & Gallic acid \\
\hline N2 & 0.88 & 2.94 & 9678.22 & 105.01 \\
N3 & 1.19 & 2.24 & 9090.4 & 98.64 \\
N4 & ND & 0.07 & 499.99 & 5.42 \\
N5 & 0.32 & 0.38 & 2569.83 & 27.88 \\
\hline
\end{tabular}

\section{Metals in blended wine}

Most metals are important for efficient alcoholic fermentation (Pohl 2007). $\mathrm{Cu}$, $\mathrm{Fe}$ and $\mathrm{Mn}$ are responsible for changes in stability of old wine and modification of the sensory quality of wine after bottling. Palm wine contains following metals $\mathrm{Cu}$ (0.85 to $\left.2.05 \mathrm{mg} \mathrm{kg}^{-1}\right), \mathrm{Fe}$ (95.15 to142 $\left.\mathrm{mg} \mathrm{kg}^{-1}\right), \mathrm{Mn}$ ( 2.25 to $3.45 \mathrm{mg} \mathrm{kg}^{-1}$ ), $\mathrm{Ni}\left(1.85\right.$ to $\left.1.95 \mathrm{mg} \mathrm{kg}^{-1}\right), \mathrm{Cr}\left(13.85\right.$ to $\left.31.5 \mathrm{mg} \mathrm{kg}^{-1}\right), \mathrm{Cd}\left(0\right.$ to $\left.1.15 \mathrm{mg} \mathrm{kg}^{-1}\right), \mathrm{Zn}$ (6.35 to $10.55 \mathrm{mg} \mathrm{kg}^{-1}$ ), $\mathrm{Pb}$ (1.9 to $3.5 \mathrm{mg} \mathrm{kg}^{-1}$ ) as shown in Fig.2 and Fig.3.The level of metals in the blended palm wine was found in the decreasing concentration order of metals $\mathrm{Fe}>\mathrm{Cr}>\mathrm{Zn}>\mathrm{Cu}>\mathrm{Mn}>\mathrm{Pb}>\mathrm{Ni}>\mathrm{Cd}$. Elements estimated in palm sap blended wine exceed Organisation of Vine and Wine (OIV) recommendations except for copper. This may be due to presence of elements in palm sap itself.

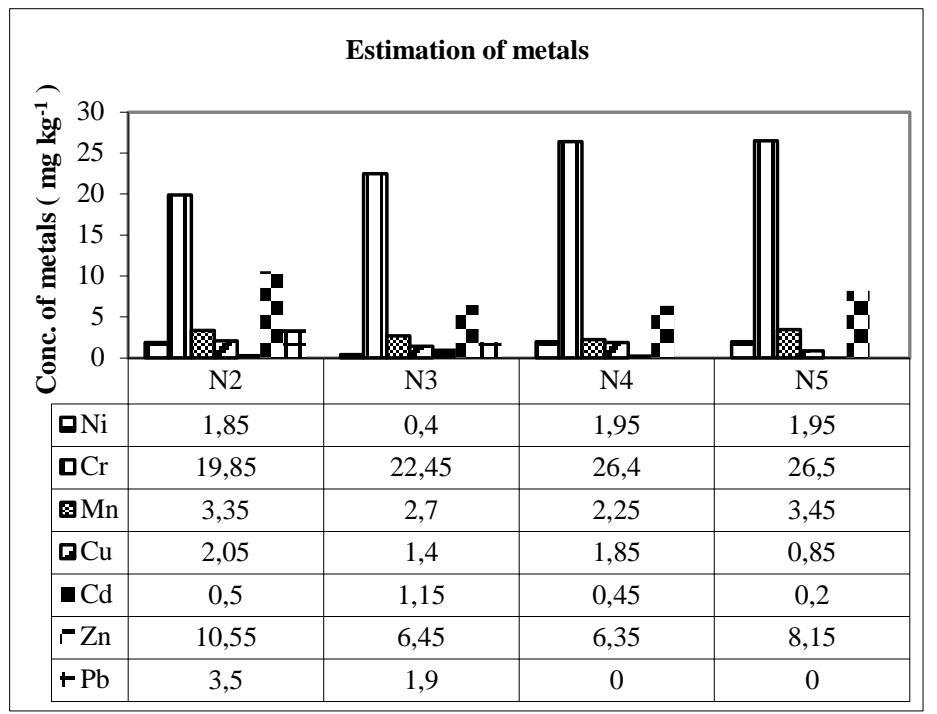

Figure 2 - Concentration of metals in wine

Fe concentration of $142 \mathrm{mg} \mathrm{kg}^{-1}$ was found in blended palm wine N5 compare to $3.16 \mathrm{mg} \mathrm{kg}^{-1}$ (Woldemariam, 2011) and $12.5 \mathrm{mg} \mathrm{kg}^{-1}$ (Nikolakaki, 2002). In case of $\mathrm{Zn}$ higher concentration of $10.55 \mathrm{mg} \mathrm{kg}^{-1}$ in N2 blended combination was estimated compare to $2.7 \mathrm{mg} \mathrm{kg}^{-1}$ (Woldemariam, 2011) and $5.5 \mathrm{mg} \mathrm{kg}^{-1}$ (Nikolakaki, 2002). Maximum Mn concentration was estimated to be $3.45 \mathrm{mg}$ $\mathrm{kg}^{-1}$ in N5, compare to $1.88 \mathrm{mg} \mathrm{kg}^{-1}$ (Woldemariam 2011) and $2.2 \mathrm{mg} \mathrm{kg}^{-1}$ (Nikolakaki, 2002). $\mathrm{Ni}$ concentration found less in $\mathrm{N} 3\left(0.4 \mathrm{mg} \mathrm{kg}^{-1}\right)$ and maximum in $\mathrm{N} 4$, N5 compare to less than $10 \mathrm{mg} \mathrm{kg}^{-1}$ (Nikolakaki ,2002). Maximum concentration of $\mathrm{Cd}$ estimated was $1.15 \mathrm{mg} \mathrm{kg}^{-1}$. Ethiopian wines reported less than $0.01 \mathrm{mg} \mathrm{kg}^{-1}$ of $\mathrm{Cd}$ (Woldemariam, 2011).Cu element was found in $\mathrm{N} 2$ was $2.05 \mathrm{mg} \mathrm{kg}^{-1}$. Ethiopian wines reported concentration $\mathrm{Cu} 1.5 \mathrm{mg}$ $\mathrm{kg}^{-1}$ (Woldemariam, 2011). Cr concentration of estimated to be $26.5 \mathrm{mg} \mathrm{kg}^{-1}$ in N5 blending combination.

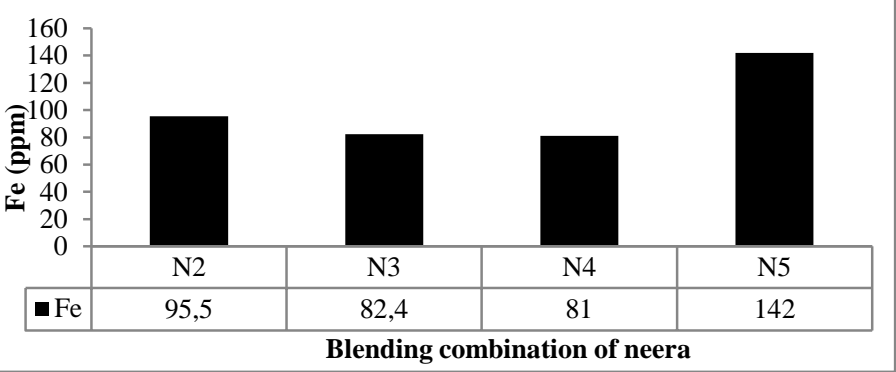

Figure 3 Concentration of $\mathrm{Fe}$ in wine

\section{Antioxidant assay}

All the blending combination exhibited radical scavenging activity. The stronger radical scavenging activity of $2.5 \mathrm{mmol} \mathrm{TE} / \mathrm{L}$ was estimated in $\mathrm{N} 3$ blending combination as shown in Fig.4. Least antioxidant activity of $2.3 \mathrm{mmol} \mathrm{TE} / \mathrm{L}$ was estimated in N2. $2.4 \mathrm{mmol} \mathrm{TE} / \mathrm{L}$ was estimated in N4 and N5 respectively. Market wine of Cabernet Sauvignon was exhibiting antioxidant activity of $2.1 \mathrm{mmol} \mathrm{TE} / \mathrm{L}$. It is low compare to other wine produced for the current investigation. Antioxidant activity of $8.22-11.43 \mathrm{mmol} \mathrm{TE} / \mathrm{L}$ was determined in Croatian red wines (Piljac et al., 2007). Antioxidant activity of 13.2-17.8 mmol TE/L (DPPH method) for Slovak and Austrian red wines (Stasko et al., 2008). Conventional wines was exhibiting antioxidant activity between 14.6 to $26.4 \mathrm{mmol} \mathrm{TE} / \mathrm{L}$ (Garaguso et al., 2015). All the combination of wines produced in the current investigation is exhibiting strong antioxidant activity. 


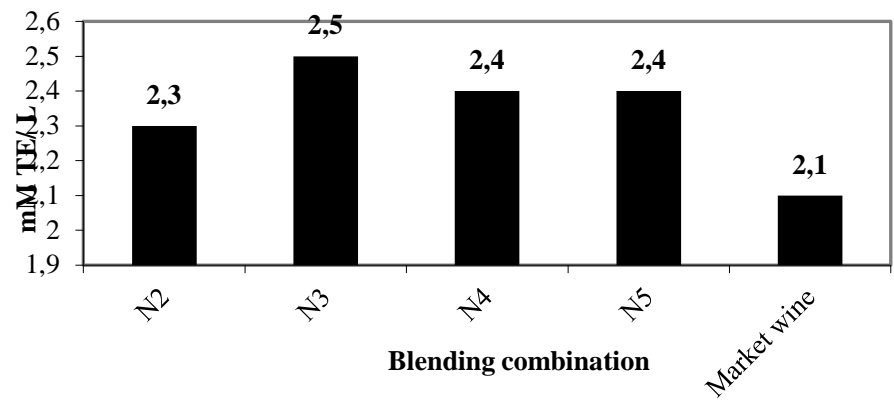

Figure 4 - Radical scavenging activity of wine

\section{Residual sugar}

Amount of residual sugar present is within $2 \mathrm{mg} / \mathrm{ml}$ as shown in Fig.5. As the weight of raisin in blended combination decreased, residual sugar concentration increased. In case of $\mathrm{N} 2$ and $\mathrm{N} 3$ combination Oenococcus oeni must have reached death phase and couldn't metabolize carbohydrates completely. N4 combination shows maximum residual sugar concentration of $1.73 \mathrm{mg} / \mathrm{ml}$. In case of N4 combination Oenococcus oeni probably has reached death phase soon, it is supported by lower VA value of $\mathrm{N} 4$ combination, i.e. $0.7 \mathrm{~g} / \mathrm{L}$ acetic acid Oenococcus oeni initially metabolized sucrose and further raffinose, arabinose present in the wine, since yeast cannot metabolize these sugars. During the raffinose and arabinose metabolism due to alpha-galactosidase metabolism sucrose and galactose will be released. N5 combination has $0.54 \mathrm{mg} / \mathrm{ml}$ of residual sugar.

\section{Ethanol}

Ethanol concentration was found to be in the range of 12 to $13 \%(\mathrm{v} / \mathrm{v})$.

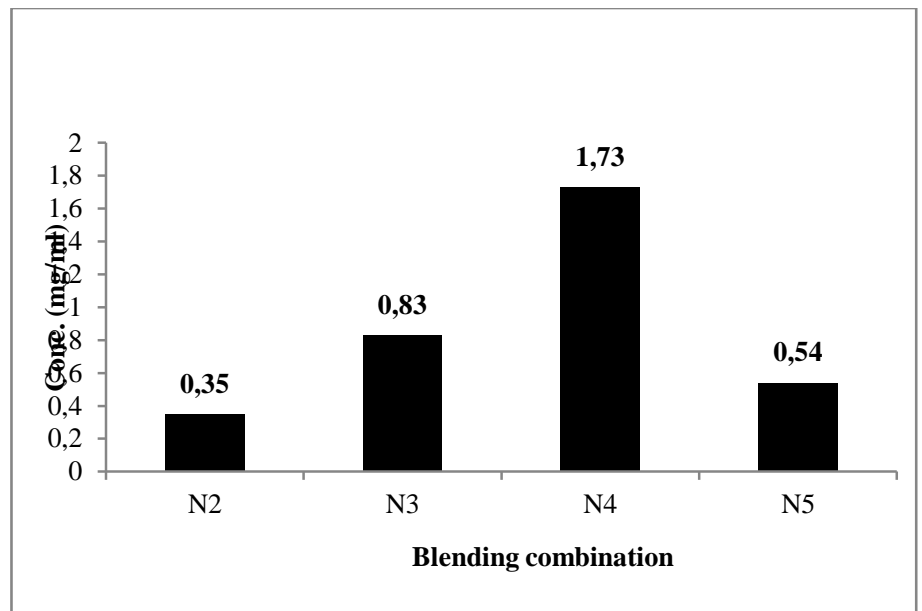

Figure 5 - Residual sugar concentration

\section{CONCLUSION}

The Current investigation has revealed that concoction palm wine is a promising alternative for the existing low cost palm wine. Fixed acidity in terms of tartaric acid equivalent was found to be in the range of $3.31 \mathrm{~g} / \mathrm{L}$ to $6.18 \mathrm{~g} / \mathrm{L}$. All the blended wine had revealed potential radical scavenging activity and maximum activity of $2.5 \mathrm{mM}$ TE/L was estimated in N3. Polyphenols were present in higher concentration. Further research is desirable in documenting oragnoleptic properties and scale-up of the process.

Acknowledgments: The authors gratefully acknowledge Mr. Purushotham, Mr.Suresh Haleyangadi for providing unfermented palm sap as per the requirement.

\section{REFERENCES}

A. Vilela-Moura, D. Schuller, V. Falco, A. Mendes-Faia, M. and Corte-Real (2010). Effect of refermentation conditions and micro-oxygenation on the reduction of volatile acidity by commercial S. cerevisiae strains and their impact on the aromatic profile of wines. International Journal of Food Microbiology 141: 165-172. http://dx.doi.org/10.1016/j.ijfoodmicro.2010.05.006
D. Fracassetti , N. Lawrence, A.G.J. Tredoux, A. Tirelli, H.H. Nieuwoudt and W.J. Du Toit. ( 2011). Quantification of glutathione, catechin and caffeic acid in grape juice and wine by a novel ultra-performance liquid chromatography $\begin{array}{llll}\text { method. Food 1136-1142. } & \end{array}$ http://dx.doi.org/10.1016/j.foodchem.2011.04.001

Daniel Minilu Woldemariam and Bhagwan Singh Chandravanshi .(2011) Concentration levels of essential and non-essential elements in selected ethiopian wines. Chemical Society of Ethiopia 25(2), 169-180. http://dx.doi.org/10.4314/bcse.v25i2.65852

F. Jimenez Marquez, J. Vazqueza, J. Úbeda and J.L. Sanchez-Rojas. (2013). Low-cost and portable refractive optoelectronic device for measuring wine fermentation kinetics. Sensors and Actuators 178: 316- 323 http://dx.doi.org/10.1016/j.snb.2012.12.091

Frank N. I. Morah. (1994). Effect of metabisulphite on alcohol production in palm-wine. Food Chemistry 53: 153-156. http://dx.doi.org/10.1016/0308 8146(95)90781-2

Galani-Nikolakaki S., Kallithrakas-Kontos N. and Katsanos AA. (2002). Trace element analysis of Cretan wines and wine products. Sci. Total environment 285:155-163. http://dx.doi.org/10.1016/S0048-9697(01)00912-3

Havva Nilgun Budak and Zeynep B. Guzel-Seydim. (2010). Antioxidant activity and phenolic content of wine vinegars produced by two different techniques. Journal of Sci. Food Agriculture 90: 2021-2026. http://dx.doi.org/10.1002/jsfa.4047

Ivana Garaguso and Mirella Nardini. (2015). Polyphenols content, phenolics profile and antioxidant activity of organic red wines produced without sulfur dioxide/sulfites addition in comparison to conventional red wines. Food chemistry 179: 336-342. http://dx.doi.org/10.1016/j.foodchem.2015.01.144

Jean L. Jacobson. (2006). Introduction to wine laboratory practices and procedures. $1^{\text {st }}$ ed., Springer Science Business Media, Inc. New York.

Katja Vahl, HeikeKahlert, Lisandrovon Muhlen, Anja Albrecht, Gabriele Meyer and Jurgen Behnert. (2013). Determination of the titratable acidity and the $\mathrm{pH}$ of wine based on potentiometric flow injection analysis. Talanta 111:134-139. http://dx.doi.org/10.1016/j.talanta.2013.02.057

Keren Bindon, Cristian Varela, James Kennedy, Helen Holt and Markus Herderich .(2013). Relationships between harvest time and wine composition in Vitis vinifera L.cv. Cabernet Sauvignon 1. Grape and wine chemistry. Food chemistry 138:1696-1705. http://dx.doi.org/10.1016/j.foodchem.2012.09.146

Law S. V., Abu Bakar F., Mat Hashim D. and Abdul Hamid A.(2011). Popular fermented foods and beverages in Southeast Asia. International Food Research Journal 18: 475-484.

Marijan Seruga, Ivana Novak and Lidija Jakobek.(2011). Determination of polyphenols content and antioxidant activity of some red wines by differential pulse voltammetry, HPLC and spectrophotometric methods. Food Chemistry 124:1208-1216. http://dx.doi.org/10.1016/j.foodchem.2010.07.047

Michael O. Eze and A.Uzoechi Ogan. (1988). Sugars of the unfermented sap and the wine from the oil palm, Elaeis guinensis, tree. Plant Foods for Human Nutrition 38:121-126.

Miller G.L. (1959). Use of dinitrosalicylic acid reagent for determination of reducing sugar. Anal. Chem.31(3):426 - 428

Nair Olguín, Albert Bordons and Cristina Reguant. (2009). Influence of ethanol and $\mathrm{pH}$ on the gene expression of the citrate pathway in Oenococcus oeni. Food microbiology 26: 197-203. http://dx.doi.org/10.1016/j.fm.2008.09.004

Okafor N. (1972). Palm Wine Yeasts from parts of Nigeria. J. Sc. fd. Agriculture 23:1399-1407.

Ola Lasekan and Sabine Otto. (2009). In vivo analysis of palm wine (Elaeis guineensis) volatile organic compounds (VOCs) by proton transfer reaction-mass spectrometry. International Journal of Mass Spectrometry 282:4549.http://dx.doi.org/ 10.1016/i.ijms.2009.02.005

P. Pohl. (2007). What do metals tell us about wine? Trends in Analytical Chemistry 26:941-949.http://dx.doi.org/10.1016/j.trac.2007.07.005

Pedro Mena, Amadeo Gironés-Vilaplana, Nuria Martí and Cristina GarcíaViguera. (2012). Pomegranate varietal wines: Phytochemical composition and quality parameters. Food chemistry 133:108-115 http://dx.doi.org/10.1016/j.foodchem.2011.12.079

Piljac-Zegarac, J., Martinez, S., Valek, L., Stipcevic , T. and Kovacevic-Ganic K. (2007). Correlation between the phenolic content and DPPH radical scavenging activity of selected Croatian wines. Acta Alimentaria 36:185-193. http://dx.doi.org/10.1556/AAlim.2007.0005

Sekar, S. and Mariappan S. (2005). Usage of traditional fermented products by Indian rural folks and IPR. Indian Journal of Traditional Knowledge 6 (1): 111120

Stasko, A., Brezova, V., Mazur, M., C ertik, M., Kalinak, M. and Gescheidt G. (2008). A comparative study on the antioxidant properties of Slovakian and Austrian wines. LWT- Food Science and Technology 41:2126-2135. http://dx.doi.org/10.1016/j.lwt.2007.11.021

T. R. Shamala and K. R. Sreekantiah. (1988) Microbiological and biochemical studies on traditional Indian palm wine fermentation. Food chemistry 5:157-162 http://dx.doi.org/10.1016/0740-0020(88)90014-7

Tuley P. (1965). Studies on the production of wine from the oil palm. J Nigerian Inst Oil Palm Res. 4:283-289. 